\title{
Factors Influencing Departmental Responses to the Development Goals for the State Services
}

\author{
Gary McAdam
}

\section{Introduction}

Since the mid 1990s significant effort has been put into addressing the fragmentation effects of the state sector $^{1}$ reforms of the 1980 s. Several attempts ${ }^{2}$ have been made under different governments to reduce fragmentation and ensure alignment and integration of activity across the public service and, more recently, the broader state services. ${ }^{3}$ These efforts have increasingly sought to use non-structural means to improve collaboration and coordination. Over recent years they have had a significant focus on improving the outcomes experienced by the community and improving service delivery to citizens.

It is not clear what influences the way in which agencies in the state services respond to these centrally-driven initiatives, and, therefore, the ability of such initiatives to drive significant change in the dynamics they are aiming to affect. While such initiatives are usually driven from the centre of government, they rely on a rather dispersed set of state services agencies, each with their own focus and priorities, to implement them. The research summarised in this article looked at this issue in the context of one of the more recent centrally-driven initiatives, the Development Goals for the State Services (the goals).

1 The state sector includes: all the state services (see note 3); some departments that are not part of the state services; tertiary education institutions; offices of Parliament; and state-owned enterprises (SSC, undated).

2 Strategic Result Areas (SRAs) were defined in 1994. These were replaced by Key Government Goals in 2001. Following the Review of the Centre in 2001, departments were required to implement Managing for Outcomes (MfO), and a service-wide focus on leadership and people management issues was reasserted.

3 The state services consists of: all public service departments; other departments that are not part of the public service; all Crown entities (except tertiary education institutions); a variety of organisations included in the government's annual financial statements by virtue of being listed on the fourth schedule to the Public Finance Act; and the Reserve Bank of New Zealand (SSC, undated).

\section{The Development Goals for the State Services}

The Development Goals for the State Services were defined by the State Services Commission and were launched with the support of the government in 2005 (SSC, 2006). They include an overall goal: 'A system of world class State Services, serving the government of the day and meeting the needs of New Zealanders', and a set of subsidiary goals (see Table 1 ).

Table 1: Development Goals for the State Services

\begin{tabular}{|l|l|}
\hline Goal & Description \\
\hline $\begin{array}{l}\text { Employer of } \\
\text { Choice }\end{array}$ & $\begin{array}{l}\text { Ensure the State Services is an } \\
\text { employer of choice attractive } \\
\text { to high achievers with a } \\
\text { commitment to service. }\end{array}$ \\
\hline $\begin{array}{l}\text { Goal 2 } \\
\text { Excellent State } \\
\text { Servants }\end{array}$ & $\begin{array}{l}\text { Develop a strong culture of } \\
\text { of excellence. }\end{array}$ \\
\hline $\begin{array}{l}\text { Goal 3 } \\
\text { Networked } \\
\text { State Services }\end{array}$ & $\begin{array}{l}\text { Use Technology to transform } \\
\text { the provision of services for }\end{array}$ \\
\hline $\begin{array}{l}\text { Goal 4 } 4 \\
\text { Coordinated } \\
\text { State Agencies }\end{array}$ & $\begin{array}{l}\text { Ensure the total contribution of } \\
\text { government agencies is greater } \\
\text { than the sum of its parts. }\end{array}$ \\
\hline $\begin{array}{l}\text { Goal 5 } \\
\text { Accessible } \\
\text { State Services }\end{array}$ & $\begin{array}{l}\text { Enhance access, responsiveness } \\
\text { and effectiveness, and improve } \\
\text { State Services. }\end{array}$ \\
\hline Goal 6 & $\begin{array}{l}\text { Strengthen trust in the State } \\
\text { of service. }\end{array}$ \\
\hline
\end{tabular}

Source: SSC, 2006, p.9 


\section{Purpose of the goals}

Publicly available documentation suggests that the goals aim to ensure that the state services effectively support New Zealand's economic and social success. It is noted by the State Services Commission that 'A well performing State Services can make a huge difference - to New Zealand's success as a country and to the people that make up our society', and that 'An effective State Services is integral to the country's economic and social performance' (SSC, 2005a, p.1).

However, other driving purposes became clear during the course of the research. The state services commissioner, Mark Prebble, noted that the goals are as much about transforming the commission as they are about transforming the state services. On a more personal level, the goals are being used to communicate the commissioner's intent for his term in office (Prebble, 2006).

While connected to past reform efforts, the goals are clearly intended to drive significant change in the way state services are delivered in the future. The goals aim to 'outline the future direction for New Zealand's State Services' (SSC, 2005b, p.1) and 'provide a framework for delivering the next generation of State Services' (SSC, 2006, p.6). They are described as moving from a reform focus to a development focus (SSC, 2005a).

Importantly, the goals are characterised by the commission as being about how New Zealand's state services will operate, not what they will achieve: 'These goals do not outline what the State Services will achieve (such as support for families), as that is a matter of government policy. Rather, the goals are aspirations for how the State Services will be arranged and perform' (SSC, 2005a, p.2).

\section{Context for implementation of the goals}

The commission recognises that achievement of the goals requires contributions from all parts of the state services, and that this may require some change in behaviour:

To accomplish this, we will need to work together more effectively. At times this will require us to make decisions that put the interests of the State Services above those of our individual agencies. This will necessitate a broadening of our strategic vision and of our concepts of leadership, and trust in each other's ability to lead and to deliver that vision. This collaborative approach may also present some challenges in the short term. (SSC, 2006, p.5)

\section{Research method}

The research sought to identify the factors that have influenced the ways in which a sample of departments have responded to the goals. To do this, it explored how the goals were developed and communicated and how they are being responded to by those departments. On the basis of this information, conclusions were drawn about the nature of departmental responses to the goals, and the factors that have influenced those responses.

The research entailed:

- reviewing publicly available literature relating to the goals to determine the broad intentions and structure of the goals, and any specific expectations relating to them;

- reviewing the literature relating to corporate strategy and change management to define an appropriate framework for the analysis;

- conducting a structured interview with the state services commissioner in order to gain greater insight into the intentions behind development of the goals, the process by which they were developed, and the specific expectations of agencies in the state services;

- conducting structured interviews with informants in five public service departments to determine how they have responded, and the factors that have influenced the nature and content of their responses. Tier 2 senior managers with organisational responsibility for strategy and/or planning were selected for interview as they were considered to be in critical positions in terms of both translating their chief executives' wishes in respect of the goals into organisational reality, and providing leadership for reflecting the goals in organisational direction and strategy (interviews were undertaken during December 2006); and

- undertaking a content analysis of the information gathered, to identify factors that have influenced departmental responses to the goals. 


\section{Framework for the research}

Following a review of strategy and change management literature, eight factors were identified as being significant in the development and implementation of successful strategic change, and were therefore deemed to provide a useful framework for the research. These factors were translated into a number of propositions,

Table 2: Propositions tested in the research

\begin{tabular}{|c|c|}
\hline oposition 1 & $\begin{array}{l}\text { There will be a clear understanding of the goals and a strong sense of shared vision amongst } \\
\text { the departmental informants. This will be reflected in: } \\
\text { - understanding of the goals, including clarity about, and consistency of view of, the } \\
\text { difference that is being sought; } \\
\text { - a sense that the goals are important and worthy of effort; and } \\
\text { - a sense of empowerment to pursue them. }\end{array}$ \\
\hline Proposition 2 & $\begin{array}{l}\text { There will be an evident sense of urgency amongst informants. This will be reflected in: } \\
\text { - communication of a sense of urgency to departments through the communications and } \\
\text { actions of the central agencies; and } \\
\text { - active planning by agencies in pursuit of the goals, including planning for short-term wins. }\end{array}$ \\
\hline Proposition 3 & $\begin{array}{l}\text { Departmental informants will perceive there being strong leadership behind the goals. This } \\
\text { will be reflected in: } \\
\text { - a strong sense of joint leadership coming from the central agencies; } \\
\text { - a strong sense of ownership and leadership in pursuit of the goals coming from their chief } \\
\text { executives, both individually and collectively; and } \\
\text { - awareness that there are expectations of change, at a political level, in the way the state } \\
\text { services operate. }\end{array}$ \\
\hline Proposition 4 & $\begin{array}{l}\text { Specific processes will have been developed for communicating and implementing the goals, and } \\
\text { monitoring performance in relation to them. These will be supportive of, and integrated with, other } \\
\text { management processes, at both service-wide and departmental levels. This will be reflected in: } \\
\text { - identifiable processes for communicating, implementing and assessing progress against the } \\
\text { goals; and } \\
\text { - integration of these processes with existing management processes, where practicable. }\end{array}$ \\
\hline Proposition 5 & $\begin{array}{l}\text { The goals, and the actions taken in pursuit of them, will have been actively communicated } \\
\text { across and within departments to enrol the managers and staff of those organisations in } \\
\text { pursuit of the goals. This will be reflected in: } \\
\text { - active communication across departments, targeted at many levels; and } \\
\text { - wide communication within departments. }\end{array}$ \\
\hline Proposition 6 & $\begin{array}{l}\text { There will be clear processes for planning actions in pursuit of the goals, which provide } \\
\text { sufficient structure to guide and motivate action but allow sufficient flexibility for } \\
\text { departments to define the distinctive contributions they can make. This will be reflected in: } \\
\text { - existence of an implementation plan or plans, and awareness of those plans amongst } \\
\text { departmental informants; } \\
\text { - evidence that departments had contributed to the planning; } \\
\text { - evidence of active planning within departments in pursuit of the goals. }\end{array}$ \\
\hline Propo & $\begin{array}{l}\text { There will be clear markers of the changes expected as a result of pursuit of the goals, and } \\
\text { mechanisms to assess progress. These will be reflected in: } \\
\text { - clear milestones or indicators of expected progress or performance; and } \\
\text { - an established process for assessing progress or performance against the goals. }\end{array}$ \\
\hline
\end{tabular}


reflecting desirable characteristics of a good quality process of strategic change (Table 2). The extent to which these characteristics existed in implementation of the Development Goals was tested through the interviews with departmental informants.

\section{Findings from interviews with depart- mental informants}

\section{Clarity of direction and shared vision}

Informants' responses indicated that there is a clear understanding of directions being pursued by the goals and an understanding of their importance to the future performance of New Zealand's state services. Most informants were able to identify the key drivers that led to the goals, and showed a clear understanding of the directions being pursued. However, a number of informants considered the goals to be so self-evident as to be almost passé. This must raise questions about the ability of the goals to motivate new behaviours and actions.

While all informants felt that their departments were able to pursue the goals, there was some sense that they may face constraints which will limit the extent to which they do so. This was reflected in a view that there are actual or potential cost implications in pursuing the goals, and little incentive, in terms of the way departments are funded, to pursue them beyond the point where there is sound business logic for the department. This has possible implications for the pursuit of cross-departmental initiatives, particularly where the 'value proposition' for each of the agencies is insufficient to incentivise action, notwithstanding potential benefits for the broader system as a whole.

\section{Sense of urgency}

Feedback from informants suggested that no particular sense of urgency is felt by the departments of the informants participating in this research. The informants indicated a lack of clarity as to what is expected of their departments, and that their departments have responded by continuing to do what they were already doing, or were planning to do anyway. While they considered this to be well aligned with the goals, there was no sense from the informants that the goals and the associated milestones have inspired any rethinking of departmental plans. This approach has been reinforced by an apparent low-key approach to the goals by their key State Services Commission contacts.

\section{Leadership}

Departmental informants saw little visible leadership in relation to the goals. Beyond the obvious leadership of the state services commissioner in developing and initially communicating the goals, departmental informants had not seen the commission demonstrating active leadership in its ongoing interactions with departments, nor had they seen evidence of joint leadership from the central agencies. Perhaps more importantly, they had not seen active leadership from their chief executives. While some chief executives had distributed communications from the commissioner, informants did not convey the impression that their chief executives had demonstrated a sense of ownership of the goals or the broader vision underpinning them.

Departmental informants did not perceive there to be a strong drive from ministers behind the goals. While most informants understood that the goals had been endorsed by Cabinet, this was seen more as a matter of form than of substance. Informants saw the goals as addressing issues that are primarily of interest to the commissioner, and have no expectation that their ministers will have any real interest in their departments' performance in relation to them.

\section{Enabling structures}

Most informants were aware of a number of the processes used by the commission to communicate and implement the goals, but were unclear about how some of the key processes are to be used. There was a reasonable awareness of the use of chief executives' periodic meetings with the commissioner for communications to chief executives relating to the goals, and of the use of Devcon ${ }^{4}$ for broader communication to senior managers. There was also a common expectation that the normal performance assessment process for chief executives would be used to assess the extent to which departments were contributing to the goals. However, while most informants were aware of, or had been involved in, the development of plans setting out their department's contributions to the goals, there was little sense of any specific expectations the commission had of departments' contributions, or how the plans were going to be used. Because of this, some informants had the view that the process was hastily

4 An annual conference for senior leaders in the state services, hosted by the State Services Commission. 
developed or had the feel of a compliance exercise about it. While there was some variability of experience across departments, on the whole the commission's relationship processes with departments appear not to have been used effectively in support of the goals.

All informants' departments had subsumed goal-related activities within normal planning and development activities. Apart from the processes necessary to respond to the commission's request for a goal-related plan, only one informant could point to a specific process that had been put in place to internally monitor contributions to the goals. This is perhaps reflective of the fact that the goals had not led to departments reviewing existing initiatives or undertaking new initiatives.

\section{Communication}

The goals have been widely communicated across departments, but to a relatively narrow group of people. The commission's communications had primarily been channelled through chief executives, with a reliance on them to transmit the messages more broadly within their departments. Devcon and presentations to a few departmental management teams had been used to communicate directly to the broader group of senior managers. The only communication channels with potentially wider audiences that were used were the commission's website and delivery of presentations to particular interest groups.

Communication within departments has also been limited. Senior managers in some departments were aware of, or had received a copy of, the commissioner's initial letter outlining the goals. While a number of departments referred to the goals in their statement of intent, and in related communications to staff, most did so in a way that was relevant to their own existing contributions, as opposed to setting the scene for any broader transformation of the state services.

As a consequence, departmental informants were of the view that there has been little penetration of the goals or the underlying vision through their departments. Communications were thought to have been sufficient to create awareness (as opposed to understanding) of the goals amongst senior managers, and some greater understanding amongst managers of particular functions. However, there was thought to be little awareness of the goals more broadly amongst departmental staff.

\section{Planning}

Implementation planning undertaken by the commission appears to have had little visibility. The initial plan developed by the commissioner, in which the draft goals were first set out, was a plan for transformation of the State Services Commission (Prebble, 2005), not of the state services, and was not widely available. While more plans and reports, such as the State of the Development Goals Report 2006 (SSC, 2006), have subsequently emerged, these do not appear to have firmly registered with the departmental informants. Furthermore, departmental informants had gained little confidence from their dealings with the commission that there was actually 'a plan', as opposed to a series of ad hoc processes.

Departmental planning in relation to the goals has been cursory. It would be an overstatement to say that departments were actually 'planning' in pursuit of the goals. Rather, they were aligning current and already planned initiatives with the goals, reflecting the view that they were already well placed in pursuing the issues the goals are seeking to advance. To this extent, they were committed to their plans. However, this has obvious limitations, and, as one informant pointed out, there is little incentive for departments to plan initiatives beyond what makes good business sense in their own context.

\section{Indicators of progress}

The issues in this area are being addressed by the commission. The goals include clear milestones for 2007 and 2010. In addition, an initial report has been published (SSC, 2006) setting out the current situation and a framework for assessing progress against the milestones. Interestingly, while this substantial document was published some months before the interviews with departmental informants were carried out, the fact that few referred to it in their comments suggests a relatively low level of awareness of its existence.

However, the milestones may not be particularly challenging for these departments. The commissioner noted that they had consciously been set at a 'safe' level, because of the lack of consultation in their development (interview with Mark Prebble). It was clear from the comments of informants that the milestones were not challenging their departments to move beyond what they were currently doing. 


\section{Summary of research findings}

A number of factors appear to have influenced the way in which the departments in the sample covered by this research have responded to the Development Goals for the State Services:

\section{Understanding of the context}

Departmental informants demonstrated a good understanding of the context within which the goals were developed, and the drivers for their development. They were aware of the recent history of state sector reforms and were easily able to place the key issues the goals are designed to pursue. They saw their departments as being attuned to, and having been in the process of addressing, most of these issues prior to the advent of the goals, and therefore as not needing to make additional efforts in response to the goals.

\section{Perceptions of the purposes of the goals}

Two underlying purposes predominated in informants' thinking about the purposes of the goals. First, there was a strong view amongst informants that the goals are significantly, if not primarily, intended to provide a vehicle for the State Services Commission to develop a more relevant and sustainable role for itself. The second factor, which is related to the first, is the need for a common frame of reference for the broader state services, now that the commissioner's mandate has been extended to the state services. As neither of these purposes relate directly to departments, the goals were not seen by informants to require any special effort by their departments.

\section{The degree of active leadership}

Departmental informants had seen little active leadership relating to the goals. They had observed a low-key approach from their State Services Commission contacts and had concluded that there is little ministerial interest in the goals. Importantly, they had not detected, amongst their chief executives, a desire to actively pursue the goals beyond what their departments were planning already.

\section{The degree of challenge}

The goals and their related indicators were not perceived as requiring a stretch by informants' departments. Most informants were unclear as to what specifically is expected of their departments. As a result of this, and of the lack of any sense, in their dealings with commission staff, that a stretch or special effort was expected, their departments have felt comfortable that merely repackaging existing initiatives that are consistent with the goals is sufficient to fulfil any requirements of them.

\section{Key issues for consideration}

These factors raise some issues that the commissioner may usefully consider in refreshing the goals process.

\section{Chief executives' leadership}

One of the key challenges going forward is the need to ensure that chief executives take a visibly active role in leading activity in pursuit of the goals. If the perceptions of the departmental informants correctly reflect the broader situation, there has not been sufficient incentive for chief executives to take a proactive role in pursuit of the goals, particularly as may be necessary to advance initiatives that go beyond the direct business interests of their departments. This is likely to require both a clearer statement of what is expected of chief executives in relation to the goals, and a greater emphasis in performance discussions on their contributions towards the goals.

More active ministerial interest may also be necessary to focus chief executives' attention on the goals. Departmental chief executives face an ambiguous authorising environment, ${ }^{5}$ in effect serving two masters: the commissioner and their minister(s). Because of this, their preparedness to actively pursue the goals beyond the point at which it makes sense from a purely internal departmental perspective will, to a significant degree, be determined by the consistency of signals from both their ministers and the commissioner that they should do so. While the goals are about how the state services operate, and in many respects transcend governments, this is intimately linked with what the state services are able to deliver, and therefore should be of interest to ministers. Ministerial support has particular significance for the desire to move to more 'joined-up' service delivery, as in many cases this will require ministerial backing, if not active ministerial leadership.

5 Moore (1995, p.119) notes that the most important figures in the authorising environments of public managers are those who 'appoint them to their offices, establish the terms of their accountability, and supply them with resources'. 


\section{Strategic stretch}

More demanding expectations and accountability are required to incentivise chief executives into action that goes beyond their own departments' direct interests. It is clear from departmental informants' feedback that while their departments are pursuing initiatives that comfortably align with the goals, they are not being stretched by the current expectations of them. A more demanding set of expectations may be necessary to encourage chief executives to move beyond this and proactively pursue initiatives that are driven from a broader perspective.

\section{Breadth of engagement}

More active engagement with senior managers in the state services will be required if they are to be enrolled in pursuit of the goals. While chief executives provide overall departmental leadership, senior managers, particularly those with strategy and planning responsibilities, are essential to ensuring that the goals are institutionalised in the strategies and plans of their departments and agencies. More active engagement with these managers on the directions, plans and expectations of departments will be essential if departmental responses are to be moved from relatively passive 'retrofitting' exercises to more active planning in pursuit of the goals. It could also be used to broaden the 'guiding coalition' for the goals to the second-tier management of departments and agencies.

\section{Clarity of plans and expectations}

The commission needs to be more consistent and wellorganised in its own interactions with departments and agencies if it is to effectively engage state services managers around the goals. Any perceived lack of coherence in the way the commission rolls out goalrelated activities, and any lack of clarity about the commission's expectations, will only serve to reinforce underlying cynicism about both the purpose of the goals and the commission's ability to provide effective leadership. Clarity and consistency of message, through both formal and informal communications, and a clear sense of 'the plan' and the expectations that go with it are necessary to provide confidence that this is a wellplanned and sustainable process.

\section{Conclusion}

If the goals are to bring about 'A system of world class State Services' they will require a rather more active approach than has been evident from the information gathered in this research. While informant perceptions indicate that departments are pursuing initiatives that are consistent with the goals, they have been driven by their own best interests, rather than by consideration of what is in the best interests of the state services more broadly. This may be a necessary first step, but is unlikely to be sufficient to achieve the aspirations encompassed in the goals.

However, it is clear from discussion with the state services commissioner that most of the issues identified in the research were not unexpected. The commissioner was aware of a number of areas that required further work, and is currently 'refreshing' the milestones and process, taking on board learnings from the process to date.

\section{Bibliography}

Alford, J. (2001) 'The implications of "publicness" for strategic management theory', in G. Johnson and K. Scholes (eds), Exploring Public Sector Strategy, Essex, UK: Pearson, pp.1-16

Hamel, G. and C.K. Prahalad (1996) 'Strategic intent', in The Strategy Process: concepts, contexts, cases, Upper Saddle River, NJ: Prentice Hall

Idenburg, P.J. (1993) 'Four styles of strategy development', in Long Range Planning, 26 (6), pp.132-7

Informant A, Transcript of interview with 'Informant A', 28 November 2006

Informant B, Transcript of interview with 'Informant B', 4 December 2006

Informant $\mathrm{C}$, Transcript of interview with 'Informant C', 6 December 2006

Informant $\mathrm{D}$, Transcript of interview with 'Informant D', 7 December 2006

Informant E, Transcript of interview with 'Informant E', 7 December 2006

Kanter, R.R., B.A. Stein and J.D. Jick (1992) 'The big three model of change', in The Challenge of Organisational Change, New York: The Free Press, pp.3-19 
Kotter, J.P. (1995) 'Leading change: why transformation efforts fail', Harvard Business Review, March-April, pp.59-67

Mintzberg, H. (1996) 'Five Ps for strategy', in The Strategy Process: concepts, contexts, cases, Upper Saddle River, NJ: Prentice Hall

Moore, M.H. (1995) Creating Public Value Strategic Management in Government, Cambridge, Mass: Harvard University Press

Prebble, M. (2005) 'Leadership of the State Services', internal paper, 4 February, Wellington: State Services Commission

Prebble, M. (2006) Transcript of interview with Dr Mark Prebble, 28 November

Public Finance Act (1989)

Quinn, J.B. (1996) 'Strategies for change', in The Strategy Process: concepts, contexts, cases, Upper Saddle River, NJ: Prentice Hall

Quinn, J.B. and J. Voyer (1996) 'Logical incrementalism: managing strategy formation', in The Strategy Process: concepts, contexts, cases, Upper Saddle River, NJ: Prentice Hall

Scott, G. (2001) Public Management in New Zealand: lessons and challenges, Wellington: NZ Business Roundtable

State Services Commission (SSC) (2005a) Development Goals for the State Services, www.ssc.govt.nz, retrieved 15 March 2006

SSC (2005b) Conference programme, Devcon Senior Leaders Development Conference 2005, Wellington

SSC (2006) State of the Development Goals Report 2006, Wellington: State Services Commission

SSC (undated) Glossary, www.ssc.govt.nz, retrieved 10 January 2007

Wickham, P. (2000) 'The nature of corporate strategy', in Financial Times Corporate Strategy Casebook, Upper Saddle River, NJ: Prentice Hall
Gary McAdam has been a public servant for more than $\mathbf{3 0}$ years, and is currently Manager of Strategy and Planning for the New Zealand Customs Service. Prior to joining Customs he was with the State Services Commission for 15 years. A graduate of Massey University, Gary undertook the research on which this article is based whilst completing a Master of Public Management degree at the School of Government, VUW. His email address is: gary.mcadam@paradise.net.nz. 